\title{
Microbiological Contamination and Food Hygiene Practices In old Restaurants In Nablus Governorate, Palestine
}

\author{
WAFAA MENAWI ( $\nabla$ w.menawi@najah.edu ) \\ An-Najah National University https://orcid.org/0000-0002-1351-5578 \\ Nada Maher Saeeri \\ An-najah National University Faculty of Medicine and Health Sciences \\ Maimona Jalal Quzmar \\ An-najah National University Faculty of Medicine and Health Sciences \\ Noor Baker Abu Hijleeh \\ An-najah National University Faculty of Medicine and Health Sciences \\ Hala Salah Alden Antar \\ An-najah National University Faculty of Medicine and Health Sciences \\ Zahra Ibrahim Soudi \\ AN NAJAH NATIONAL UNIVERSITY \\ Dana Rateb Makhlouf \\ An-najah National University Faculty of Medicine and Health Sciences
}

\section{Research Article}

Keywords: Coliform bacteria, Contamination, Coronavirus, Restaurant, Hygiene, Food safety.

Posted Date: October 28th, 2021

DOI: https://doi.org/10.21203/rs.3.rs-982041/v1

License: (1) This work is licensed under a Creative Commons Attribution 4.0 International License. Read Full License 


\section{Abstract}

Introduction: Personal hygiene is important in maintaining food quality and health safety, so the low level of personal hygiene causes contamination leading to food spoilage and the occurrence of sick cases for consumers.

Objective: This study was conducted under the Corona pandemic to verify food safety in Nablus old restaurants, Palestine, in the year 2021.

Research methodology: This study covered 32 restaurants and 160 employees randomly selected. Data collection began between April and June in 2021 using 160 questionnaires that included 20 questions were answered by workers in these restaurants.

Results: Contamination with coliform bacteria was found in the restaurant samples with a percentage (42.5\%), where the samples have taken from the tables having the highest contamination of this bacterium (50\%). Furthermore, the data revealed that there was a relationship between coliform bacteria contamination and age, educational level, and food safety training, as the contamination being seen in the group that got the training, In contrast to those who didn't at the P-value $<0.20$.

Conclusion: There was an association of bacterial contamination with age, especially among the younger group who were less concerned with hygiene and food safety practices compared to the elderly group. And it turns out that restaurant workers must be properly trained in food safety and monitored regularly.

\section{Introduction}

Because food is one of the indispensable basics of life, the health and hygiene of food have a major role in the spread of diseases as a result of the presence of microbes [1]. Bacterial contamination occurs when food is contaminated by microorganisms such as bacteria, viruses, molds, fungus, and toxins[2]. This can occur in a variety of ways, including species that generate poisons that are hazardous to humans. Despite the Ministry of Health's efforts to prevent the growth of these microbes, the food remains exposed to spoilage or contamination with them[2, 3].

Coliform bacteria are Gram-negative, non-spore-forming, facultative anaerobic rods that ferment lactose rapidly into acid and gas at $352^{\circ} \mathrm{C}$ within 24 or 48 hours, Some types of coliform bacteria are characterized by their ability to cause disease, showing symptoms similar to those of the flu to a large extent, such as stomach upset and diarrhea, but these symptoms may be mild for healthy adults, while those with weak immunity and the elderly may suffer from severe symptoms $[4,5]$.

Therefore, this study was conducted in the city of Nablus, a city north of Jerusalem that stands between two mountains with a variety of natural springs, and is one of the largest Palestinian cities in terms of population, with hundreds of restaurants[6].

Despite the fact that Nablus is one of the most attractive tourist destinations in Palestine, this study was restricted to the old restaurants in the city. Tourists from all over the world visit it, especially the old town, which has restaurants that are tens of years old, such as Al-Aqsa restaurant for kunafa and others with people constantly visiting them. These visitors vary in age, nationality, and race[7].

Food workers (restaurants) have a significant role in reducing the transmission of foodborne diseases[8], so this study took into account the detection of the presence of coliform bacteria - total coliform bacteria - using violet-red media, From food (direct) and non-food (indirect) samples such as a table, spoon, plate, etc.

\section{The purpose of this research was to:}

- Investigate the food safety in Nablus restaurants during Coronavirus Disease of 2019 (COVID 19) era. Thus, the investigation of coliform contamination in restaurants as well as food handler hygienic activities.

\section{Materials And Methods}

Sampling 
This descriptive and observational study comprised of randomly selected 32 old restaurants that have been open for at least 20 years. In addition, 160 employees working in those restaurants gave their consent to fill out a questionnaire about food hygiene practices after our explanations about the aim and method of the study.

Samples were collected between April and June in 2021, five samples were taken from the same restaurant (table, plate, spoon, disc, and knife) using transport media, and then kept in portable refrigerators until it was transferred to the incubator in a lab, taking into account public safety precautions during the COVID 19 era such as wearing masks, gloves, continuous sterilization of hands after each collection.

\section{Study Tool:}

An interviewer-administered questionnaire was performed to obtain data on restaurant food hygiene procedures while keeping absolute privacy by not providing the restaurant names or any other information about them.

The questionnaire is divided into two sections: the first section includes 6 questions about the general characteristics of the participants in the study.

The second contained 14 questions about the participants' food health practices. Food hygiene practices were measured using a five-point Likert scale that ranges from always to never.

\section{Microbiological Sample Analysis:}

After ensuring that the samples were correctly organized and preserved, the culture and media preparation processes were carried out in the research and microbiological laboratories of the Faculty of Medicine at An-Najah National University, with the following numbers: (17G0020, 17B1140) respectively.

Violet Red Bile Agar Media (VRBA) was prepared for the cultivation of coliform bacteria by mixing $38.5 \mathrm{~g}$ of powder with 1 liter of distilled water, boiling them using a magnetic field to speed up the process, then we waited until the media had cooled down a little to facilitate the process of emptying it into Petri dishes under sterile conditions by a Bunsen flame[9], VRBA is recommended by American Public Health Association (APHA) and International Organization for Standardization (ISO)[10, 11].

Due to the addition of bile salt, crystal violet, which suppresses the growth of no target Gram-positive bacteria. Coliforms rapidly metabolize the lactose in VRBA Agar and decrease the $\mathrm{pH}$ of the medium which detect by a neutral red indicator, resulting in redpurple colonies with red-purple halos[12]. See picture 1

$<<$ Insert pictures 1 here. $>>$

\section{Data analysis:}

Descriptive statistics were used and expressed using frequencies, percentages, mean, standard deviation (SD), median and interquartile range (IQR).

Mann Whitney $U$ test, which is known as a nonparametric test that focuses on frequencies was used to connect the relationship between gender and safety training with contamination of coliform bacteria in samples at P-value $<0.20$. Furthermore, the Analysis of variance (ANOVA) test was conducted for normally distributed data with more than three groups within the independent variables which link between education levels and bacterial contamination at the P-value $<0.20$.

\section{Study Ethics:}

To start this study, approval was obtained from Institutional Review Board (IRB) at An-Najah National University. In addition, the consent of the restaurant owners and employees was also obtained to collect samples and fill out the questionnaire. 


\section{Result And Discussion}

- Demographic Characteristics

Demographic characteristics of restaurant workers (gender, age, level of education, work experience, work position, and other food safety training) are shown in Table 1. This table showed that most of the restaurant workers included in the study were males $(96.3 \%)$ while females (3.8\%). The ages of the study participants ranged from 17-61 years with a median age of 28 years and an interquartile range of 44 years in the group.

Table 1

Demographic characteristics of food handlers in Nablus, Palestine

\begin{tabular}{|lll|}
\hline Demographic Characteristics & Number & Percentage \\
\hline Gender & & \\
\hline Male & 154 & $96.3 \%$ \\
\hline Female & 6 & $3.8 \%$ \\
\hline Age (Years) & & \\
\hline Median & 28 & \\
\hline Interquartile Range & 44 & \\
\hline Minimum-Maximum & $17-61$ & \\
\hline Level Of Education & & \\
\hline Primary School or Lower & 19 & $11.9 \%$ \\
\hline Secondary School & 45 & $28.1 \%$ \\
\hline High School & 4 & $2.5 \%$ \\
\hline University & 92 & $57.5 \%$ \\
\hline Work Experience & & \\
\hline Median & 72 & \\
\hline Range & & \\
\hline Minimum-Maximum & $1-45$ & \\
\hline Work Position & & \\
\hline Chef & 61 & \\
\hline Server & $74.1 \%$ \\
\hline Cleaner & & \\
\hline Had Ever Received Food Safety & Training? & \\
\hline Yes & 62 & \\
\hline No & & \\
\hline & & \\
\hline
\end{tabular}


The results also showed that the participants who attended university were slightly more than half (57.5\%) while the participants who attended high school were (2.5\%). The work experience of our study participants range was from one year to 45 years with a median of 7 years and IQR of 44 years. (45\%) of the food handler were servers. And finally, more than half $(61.3 \%)$ had never received training for food safety.

- Coliform Contamination in Samples

Based on the coliform contamination results in the samples given in Table 2. The largest proportion of contamination was found in the samples obtained from the tables $(50 \%)$, which was due to the tables' proximity to food, which contributes to the spread of foodborne illnesses. these results were agreed by Galie et al,2018; Jamal et al,2018; Patel et al,2017 [13-15], which shed light on the number of bacteria present on surfaces in contact with food in an indirect way, and this contamination may be attributed to contaminated tools used to clean these surfaces.

Table 2

Coliform contamination of old restaurant samples in Nablus, Palestine

\begin{tabular}{|llll|}
\hline Type of sample & Total & & \\
\cline { 2 - 4 } & $\begin{array}{l}\text { Sample } \\
\text { Number (160) }\end{array}$ & Contamination \\
\hline & & (n) & Percentage (\%) \\
\hline Table & 32 & 16 & $50 \%$ \\
\hline plate & 32 & 13 & $40.62 \%$ \\
\hline spoon & 32 & 11 & $34.37 \%$ \\
\hline disk & 32 & 14 & $43.75 \%$ \\
\hline knife & 32 & 14 & $43.75 \%$ \\
\hline Total positive & & 68 & $42.5 \%$ \\
\hline Total negative & & 92 & $57.5 \%$ \\
\hline
\end{tabular}

While the results showed that the percentage of contamination from spoons was the lowest (34.37\%) because most restaurants during the study period (Corona Virus) relied on the use of single-use plastic spoons.

- Food Hygiene Practices

The food hygiene practices of food handlers were shown in Table 3. $(100 \%)$ of the participants in this research washing their hands after using the toilet, and $91.9 \%$ washing their hands after cooking, which were both considered healthy behaviors. Furthermore, more than half of them (60.6\%) never keep their fingernails long as we have noticed. 
Table 3

Food Handlers Regarding Food Hygiene Practices

\begin{tabular}{|c|c|c|c|c|c|c|}
\hline \multirow[t]{2}{*}{ statement } & \multicolumn{5}{|c|}{ Frequency (\%) } & \multirow{2}{*}{$\begin{array}{l}\text { Mean } \\
\text { (SD) }\end{array}$} \\
\hline & Never & Rarely & Sometimes & Often & Always & \\
\hline 1. Wash your after using the toilet & $0(0)$ & $0(0)$ & $0(0)$ & $0(0)$ & $160(100)$ & $5(0.0)$ \\
\hline 2. Wash your hands after cooking & $0(0)$ & $0(0)$ & $9(5.6)$ & $4(2.5)$ & 147(91.9) & $4.88(0.49)$ \\
\hline 3. Wear mask (corona) & $39(24.4)$ & $28(17.5)$ & $46(28.8)$ & $9(5.6)$ & $38(23.8)$ & $2.72(1.46)$ \\
\hline 4. Use the hygiene and alcohol & $27(16.9)$ & $14(8.8)$ & $40(25)$ & 11(6.9) & $68(42.5)$ & $3.44(1.52)$ \\
\hline $\begin{array}{l}\text { 5. Wash your hands after cleaning table and } \\
\text { using cloves }\end{array}$ & $9(5.6)$ & $11(6.9)$ & 19(11.9) & $22(13.8)$ & $99(61.9)$ & $4.03(1.47)$ \\
\hline 6. Do you put the cover head while cooking & $50(31.3)$ & $29(18.1)$ & $15(9.4)$ & $4(2.5)$ & $62(38.8)$ & $2.59(1.66)$ \\
\hline 7. Keep fingernails long & $97(60.6)$ & $21(13.1)$ & $27(16.9)$ & $15(9.4)$ & $0(0)$ & $1.66(1.04)$ \\
\hline $\begin{array}{l}\text { 8. Wear jewelry such as ring when serving or } \\
\text { handling food }\end{array}$ & $70(43.8)$ & $28(17.5)$ & $11(6.9)$ & 15(9.4) & $36(22.5)$ & $2.53(1.65)$ \\
\hline $\begin{array}{l}\text { 9. Work when you are sick (such as having a flu } \\
\text { or diarrhea, corona virus ) }\end{array}$ & 136(85) & $8(5)$ & $7(4.4)$ & $5(3.1)$ & $4(2.5)$ & $1.59(1.27)$ \\
\hline 10. Overlap food dishes while serving food & 130(81.3) & $0(0)$ & $28(17.5)$ & $0(0)$ & $2(1.3)$ & $1.5(1.02)$ \\
\hline $\begin{array}{l}\text { 11. How often do you wash the cleaning cloth } \\
\text { or towels? }\end{array}$ & $9(5.6)$ & $0(0)$ & $0(0)$ & 19(11.9) & 132(82.5) & $4.66(1.0)$ \\
\hline $\begin{array}{l}\text { 12. Use the same cloth or towel to dry plates } \\
\text { and to clean tables }\end{array}$ & 107(66.9) & $0(0)$ & $17(10.6)$ & $0 .(0)$ & $36(22.5)$ & $2.56(1.88)$ \\
\hline $\begin{array}{l}\text { 13. Do you serve or handle food when you have } \\
\text { cuts on your hands/fingers? }\end{array}$ & $127(79.4)$ & $14(8.8)$ & $10(6.3)$ & $9(5.6)$ & $0(0)$ & $1.41(0.84)$ \\
\hline $\begin{array}{l}\text { 14. Your hands/finger touches the food while } \\
\text { you are serving? }\end{array}$ & $105(65.6)$ & $29(18.1)$ & $26(16.3)$ & $0(0)$ & $0(0)$ & $1.56(0.76)$ \\
\hline
\end{tabular}

$(61.9 \%)$ of participants washing their hands after cleaning the table and using gloves, as well as (2.5\%) of them working when they were sick (such as having the flu or diarrhea, coronavirus), (22.5\%) using the same cloth or towel to dry plates and clean tables. Moreover, no one serves or handles food with cuts on their hands or fingers, nor does anybody touch the food while serving.

- Age and Coliform Contamination

In this study, age was related to the contamination of coliform bacteria through the Pearson correlation coefficient. As the bacterial contamination of dishes and disk samples had a correlation with age on its value $(0.163,0.091)$ respectively, at the Pvalue $<0.20$, this correlation was in the favore of the younger group, which was less concerned with hygiene and food safety than the older group according to the results that were appeared, and that was opposite of previous research, which found that age had an impact on food safety from contamination, particularly in the elderly[16, 17]. Moreover, there is no correlation between bacterial contamination and work experience as shown in Table 4. 
Table 4

Correlations between food handlers' age and work experience with coliform contamination in old restaurants in Nablus, Palestine

\begin{tabular}{|lllll|}
\hline & \multicolumn{2}{l}{ Age } & \multicolumn{2}{l|}{ work experience } \\
\cline { 2 - 5 } & $\mathbf{r}$ & P-value & $\mathbf{r}$ & P-value \\
\hline Total coliform contamination & 0.037 & 0.643 & 0.031 & 0.698 \\
\hline Table & 0.165 & 0.368 & 0.030 & 0.871 \\
\hline plate & 0.253 & $0.163 *$ & 0.022 & 0.904 \\
\hline Spoon & 0.062 & 0.735 & 0.184 & 0.313 \\
\hline Disk & 0.304 & $0.091 *$ & 0.180 & 0.323 \\
\hline knife & 0.106 & 0.564 & 0.127 & 0.488 \\
\hline *Significance at P-value $<0.20$. & & & & \\
\hline
\end{tabular}

In Table 5, we used the Mann Whitney U test (P-value <0.20), which connects the relationship between gender and contamination in samples, showing that there was no relationship between them. It also studied the relationship between safety training and contamination in samples, where there was a correlation between bacterial contamination in samples of the spoon (0.002) and knife (0.007) with safety-trained workers.

Table 5: Gender and food safety training of food handlers were compared with coliform contamination in old restaurants in Nablus, Palestine through using Mann Whitney U test.

\begin{tabular}{|c|c|c|c|c|c|c|}
\hline \multirow{4}{*}{$\begin{array}{l}\text { Coliform contamination score } \\
\text { - }\end{array}$} & \multirow{2}{*}{\multicolumn{3}{|c|}{$\begin{array}{l}\text { Gender } \\
\text { Mean Rank }\end{array}$}} & \multirow{2}{*}{\multicolumn{3}{|c|}{$\begin{array}{l}\text { Received food safety training } \\
\text { Mean Rank }\end{array}$}} \\
\hline & & & & & & \\
\hline & \multirow{2}{*}{$\begin{array}{l}\text { Male } \\
\mathrm{n}(154)\end{array}$} & \multicolumn{2}{|l|}{ Female } & \multirow{2}{*}{$\begin{array}{l}\text { Yes } \\
\mathrm{n}(62)\end{array}$} & \multicolumn{2}{|l|}{ No } \\
\hline & & $\mathrm{n}(6)$ & P-value & & $\mathrm{n}(98)$ & P-value \\
\hline Total coliform contamination & 81.17 & 63.25 & 0.350 & 94.68 & 71.53 & $0.002 *$ \\
\hline Table & 16.77 & 8 & 0.355 & 16.4 & 16.55 & 0.967 \\
\hline Plate & 16.72 & 14.33 & 0.671 & 17.42 & 15.87 & 0.641 \\
\hline Spoon & 16.37 & 20.5 & 0.661 & 21.50 & 11.50 & $0.002^{*}$ \\
\hline Disk & 16.69 & 10.5 & 0.513 & 20.21 & 15.46 & 0.323 \\
\hline Knife & 16.50 & 7.5 & 0.349 & 20.94 & 12.06 & $0.007 *$ \\
\hline
\end{tabular}


Table 6

The relationship between food handler education and coliform contamination in old restaurants in Nablus, Palestine

\begin{tabular}{|c|c|c|c|c|c|c|c|c|c|c|}
\hline \multirow[t]{3}{*}{ FACTORS } & \multicolumn{10}{|c|}{ Levels of Education } \\
\hline & \multicolumn{2}{|c|}{$\begin{array}{l}\text { primary school or } \\
\text { lower(n=19) }\end{array}$} & \multicolumn{2}{|c|}{$\begin{array}{l}\text { secondary } \\
\text { school(n=45) }\end{array}$} & \multicolumn{2}{|c|}{ High school(n=4) } & \multicolumn{2}{|c|}{ University ( $n=92)$} & \multirow[t]{2}{*}{$\begin{array}{l}\text { F- } \\
\text { value }\end{array}$} & \multirow[t]{2}{*}{$\begin{array}{l}\mathrm{P} \text { - } \\
\text { value }\end{array}$} \\
\hline & Mean(SD) & $\begin{array}{l}95 \% \\
\mathrm{Cl}\end{array}$ & Mean(SD) & $\begin{array}{l}95 \% \\
\mathrm{Cl}\end{array}$ & Mean(SD) & $\begin{array}{l}95 \% \\
\mathrm{Cl}\end{array}$ & Mean(SD) & $\begin{array}{l}95 \% \\
\mathrm{Cl}\end{array}$ & & \\
\hline $\begin{array}{l}\text { Total coliform } \\
\text { contamination }\end{array}$ & 3.05(1.39) & $\begin{array}{l}2.38- \\
3.72\end{array}$ & $2.93(1.42)$ & $\begin{array}{l}2.51- \\
3.36\end{array}$ & $3.25(2.06)$ & $\begin{array}{l}.0304- \\
6.53\end{array}$ & $3.01(1.41)$ & $\begin{array}{l}2.72- \\
3.30\end{array}$ & 0.084 & 0.969 \\
\hline Table & $2.90(0.65)$ & $\begin{array}{l}4.45- \\
1.26\end{array}$ & $2.92(0.364)$ & $\begin{array}{l}3.16- \\
2.67\end{array}$ & $3.07(0.05)$ & $\begin{array}{l}3.9- \\
2.95\end{array}$ & $3.07(0.05)$ & $\begin{array}{l}2.98- \\
2.63\end{array}$ & 0.304 & 0.822 \\
\hline plate & $2.71(0.31)$ & $\begin{array}{l}3.20- \\
2.22\end{array}$ & $2.91(0.12)$ & $\begin{array}{l}2.85- \\
3.02\end{array}$ & $2.28(0.51)$ & $\begin{array}{l}2.50- \\
1.95\end{array}$ & $2.82(0.26)$ & $\begin{array}{l}2.94- \\
2.69\end{array}$ & 2.138 & $0.118 *$ \\
\hline Spoon & $3.05(0.12)$ & $\begin{array}{l}3.21- \\
2.89\end{array}$ & $2.86(0.24)$ & $\begin{array}{l}3.09- \\
2.64\end{array}$ & $2.80(0.33)$ & $\begin{array}{l}2.96- \\
2.64\end{array}$ & $2.91(0.35)$ & $\begin{array}{l}3.03- \\
2.78\end{array}$ & 1.44 & 0.253 \\
\hline Disk & $2.95(0.57)$ & $\begin{array}{l}4.38- \\
1.15\end{array}$ & $3.00(0.30)$ & $\begin{array}{l}3.17- \\
2.82\end{array}$ & $2.81(0.36)$ & $\begin{array}{l}3.02- \\
2.61\end{array}$ & $2.91(0.35)$ & $\begin{array}{l}3.03- \\
2.78\end{array}$ & 0.950 & 0.398 \\
\hline knife & $2.73(0.43)$ & $\begin{array}{l}3.42- \\
2.03\end{array}$ & $3.00(0.251)$ & $\begin{array}{l}3.26- \\
2.73\end{array}$ & $2.28(0.00)$ & $\begin{array}{l}2.95- \\
2.18\end{array}$ & $2.86(0.351)$ & $\begin{array}{l}2.99- \\
2.74\end{array}$ & 2.856 & $0.055^{\star}$ \\
\hline
\end{tabular}

The correlation was higher in the category of employees who got safety training as mentioned above, which suggests that the approach used to train them was inefficient and that we need to properly train and certify them in this area. At the same time, awareness programs should be launched for restaurant employees to increase knowledge of food safety and this is consistent with a study conducted in Bangladesh that talked about this[18].

- Educational Level And Coliform Contamination

Regarding educational level, which is one of the most important factors that contribute to high food safety[16], The relationship between bacterial contamination and education levels was performed by ANOVA test as shown in Table 6. The results showed that there was a high correlation between participants who attended secondary school and contamination samples in dishes and knives separately compared to the rest of the educational levels.

This indicates that those who attended high levels of education had low levels of contamination with bacteria. Therefore, we must train secondary groups with more education on food safety and health issues.

\section{Conclusion}

There was an association of bacterial contamination with age, especially among the younger group who were less concerned with hygiene and food safety practices compared to the elderly group. And it turns out that workers must be properly trained on food safety and monitored regularly.

\section{Limitations}

This study was conducted during the Coronavirus period, as most restaurants adopted the single-use plastic cutlery system, and this affected the results. So we recommended conducting it in another period to compare it with the current study results.

\section{Abbreviations}


ANOVA

Analysis of variance

APHA

American Public Health Association

COVID 19

Coronavirus Disease of 2019

IQR

Interquartile Range

IRB

Institutional Review Board

ISO

International Organization for Standardization

SD

Standard Deviation

VRBA

Violet Red Bile Agar Media

\section{Declarations}

\section{Competing Interests}

The author(s) declared that they have no potential conflicts of interest with respect to the research, authorship and publication of this article.

\section{Funding}

The author(s) disclosed receipt of the following financial support for the research, authorship, and/or publication of this article: This study was conducted as a graduation project for a BSc graduate studying in the Faculty of Medicine and Health Sciences at An-Najah National University. It received no funding from any source.

\section{Authors' contributions}

All of the listed authors contributed to the work and gave their permission for it to be published. The authors worked in a structured procedure. Dr. Wafaa suggested the idea and design the study, communicated with key participants, supervised the work, and revised the manuscript. Ms Nada Maher Saeeri, Ms Maimona Jalal Quzmar and Ms Noor Baker Abu Hijleeh completed the study's manual portion and statistical analysis, while Ms Hala Salah Alden Antar, Ms Zahra Ibrahim Soudi, and Ms Dana Rateb Makhlouf have written the manuscript.

\section{Acknowledgements}

The authors kindly acknowledge the General Directorate of Education in Health at the Palestinian Ministry of Health Dr. Abdullah Qawasmi and Dr. Zaher Nazzal the Scientific Research Coordinator, Faculty of Medicine and Health Sciences, A-Najah National University for facilitating our work in the collection of the required data.

\section{References}

1. Abdelrazig A, Mustafa K, Mohamed M. Hygienic Practices among Food Handlers in Restaurants of Al-Nohod Locality MarketWest Kordofan-Sudan-2017.International Journal of Public Health and Safety. 
2(3):p.4. https://www.hilarispublisher.com/open-access/hygienic-practices-among-food-handlers-in-restaurants-of-alnohodlocality-marketwest-kordofansudan2017.pdf.

2. Lorenzo J.M, Munekata P.E, Dominguez R, Pateiro M, Saraiva J.A, and Franco D. Main Groups of Microorganisms of Relevance for Food Safety and StabilityIn book: Innovative Technologies for Food Preservation (pp.53-107). 2017 Sep 29. DOI: 10.1016/B978-0-12-811031-7.00003-0.

3. Halkman H.B.D, Halkman A.K. Encyclopedia of Food Microbiology // Indicator Organisms. 14 April 2014.Book Second Edition. DOI: 1016/b978-0-12-384730-0.00396-7.

4. Li D, Liu S. Water Quality Monitoring in Aquaculture. 19 October 2018.DOI: https://doi.org/10.1016/B978-0-12-8113301.00012-0.

5. Wehr H.M, Frank J.F . Standard Methods for the Microbiological Examination of Dairy Products,APHA Inc. 2004.

6. Nablus, Palestine: A history of helping Palestinian villages 2020; Available from: https://www.anera.org/stories/nabluspalestine-history-helping-palestinian-villages/.

7. Sinclair F. 7 Reasons Nablus is the Food Capital of the West Bank. 27 October 2017;Culture Trip Available from: https://theculturetrip.com/middle-east/palestinian-territories/articles/7-reasons-nablus-is-the-food-capital-of-the-west-bank/.

8. Mitwalli S, Al-Khatib I.A. Food sanitation practices in restaurants of Ramallah and Al-Bireh district of Palestine. PubMed, July 2009. Al-Majallah Al-Șiḥ̣īyah Li-Sharq Al-Mutawassiṭ 15(4).DOI:26719/2009.15.4.951.

9. Leclercq A, Wanegue C, Baylaca P. Comparison of Fecal Coliform Agar andViolet Red Bile Lactose Agar for Fecal Coliform Enumeration in Foods. American Society for Microbiology 2002 Apr.DOI:1128/AEM.68.4.1631-1638.2002.

10. Salfinger Y, Tortorello M.L. Compendium of Methods for the Microbiological Examination of Foods, American Public Health Association, Washington, D.C. 2015. https://ajph.aphapublications.org/doi/abs/10.2105/MBEF.0222

11. InternationalOrganization for Standardization (ISO),Draft ISO/DIS 43. 1991.

12. Aryal S. Violet Red Bile Agar (VRBA). April 16, 2019; Available from: https://microbenotes.com/violet-red-bile-agar-vrba/.

13. Galie S, García-Gutiérrez C, Miguélez E.M, Villar C.J, and Lombó F. Biofilms in the food industry: health aspects and control methods. 898(9).DOI: 10.3389/fmicb.2018.00898

14. Jamal M, Ahmad W, Andleeb S, Jalil F, Imran M, Nawaz M. A, Hussain T, Ali M, Rafiq M, and Kamil M.A. Bacterial biofilm and associated infections. September 2017 Journal of the Chinese Medical Association. 81(7). DOI: 10.1016/j.jcma.2017.07.012

15. Patel D, Stansell J, Jaimes M, Ferris K, and Webb G. A survey of microbial contamination on restaurant nonfood contact surfaces. April 2016. DOI: https://doi.org/10.1111/jfs.12287

16. Lee H.K, Abdul Halim.H, Thong K.L, and Chai L.C. Assessment of food safety knowledge, attitude, self-reported practices, and microbiological hand hygiene of food handlers. 55(14) International Journal of Environmental Research and Public Health. DOI: 10.3390/ijerph14010055

17. Powell S.C, Attwell R.W, and Massey S.J. The impact of training on knowledge and standards of food hygiene Eth a pilot study. 1997(7). DOI: https://doi.org/10.1080/09603129773788

18. Hashanuzzaman M, Bhowmik S, Rahman S, Abu Zakaria M.U.M, Voumik L.C, and Al Mamuna A. Assessment of food safety knowledge, attitudes and practices of fish farmers and restaurants food handlers in Bangladesh. 2020 Nov 10 Journal Home Page for Heliyon.DOI: 10.1016/j.heliyon.2020.e05485.

\section{Figures}




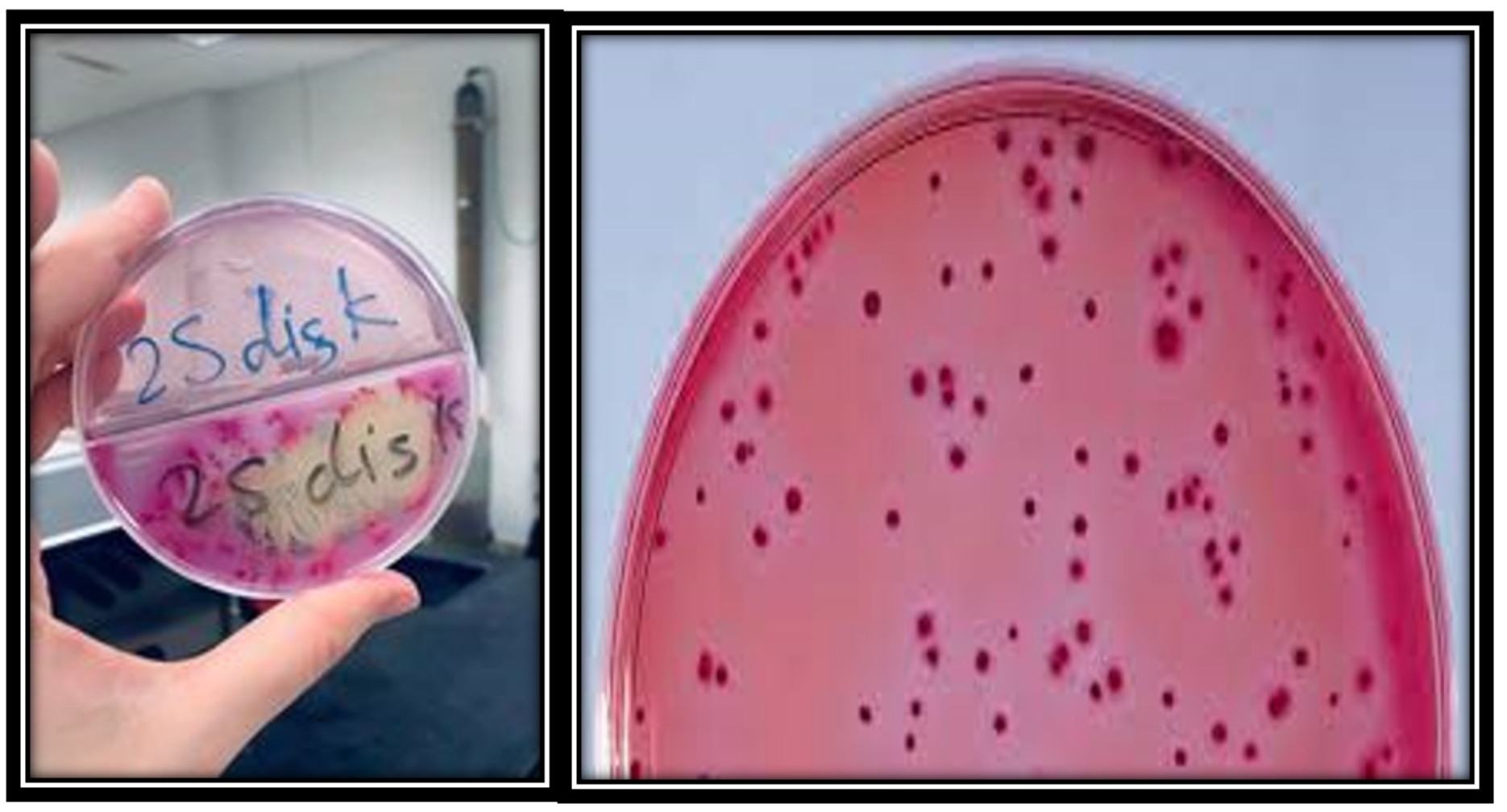

Figure 1

Due to the addition of bile salt, crystal violet, which suppresses the growth of no target Gram-positive bacteria. Coliforms rapidly metabolize the lactose in VRBA Agar and decrease the $\mathrm{pH}$ of the medium which detect by a neutral red indicator, resulting in redpurple colonies with red-purple halos[12]. 